\title{
DETECTION OF CYPERMETHRIN RESIDUES IN TOXICOLOGICAL CONTROL OBJECTS USING GAS CHROMATOGRAPHY-MASS SPECTROMETRY WITH SOLID-PHASE EXTRACTION
}

\section{IGOR M. FITSEV, OKSANA V. SHLYAMINA, ALSU R. MAKAEVA, GANNA R. NASYBULLINA \& ALEXANDER M. SAIFUTDINOV}

Research Scholar, Federal Center for Toxicological, Radiation and Biological Safety, Scientific Town,

Kazan city, Russia

\begin{abstract}
Method for determination of synthetic pyrethroid (cypermethrin) using gas chromatography-mass spectrometry (GC$M S)$ in the objects of toxicological control was carried out. The sample preparation via solid-phase extraction (SPE) with the increased capacity / selectivity concentration cartridges «Diapak C18 Plus» was used before GC-MS measurement. Methodological approach was used for quantitative determination of cypermethrin in food material, food end products, and tissues of animal/insect origin. The method is based on combination of GC-MS with electronic ionization (EI, 70 $\mathrm{eV}$ ) via SPE. It is characterized by cypermethrin limit of detection (LOD) of $3 \square \mathrm{g} \cdot \mathrm{kg}^{-1}$ and relative standard deviation (RSD) of not higher than $5 \%$. GC-MS sensitivity of cypermethrin quantitative determination is approached via selective ion monitoring (SIM/SIR-mode) with parameters of $m / z=163$ (principal ion), and $m / z=181,127$, (confirmation ions) accordingly.
\end{abstract}

KEYWORDS: Gas Chromatography-Mass Spectrometry; Objects of Toxicological Control; Synthetic Insecticides; Pyrethroids; Cypermethrin; Solid-Phase Extraction

Received: Jun 05, 2020; Accepted: Jun 25, 2020; Published: Jul 30, 2020; Paper Id.: IJMPERDJUN2020529

\section{INTRODUCTION.}

Cypermethrin-cyano (3-phenoxyphenyl) methyl3-(2, 2-dichlorovinyl)-2, 2-dimethylcyclo-propanecarboxylate-is the second-generation pyrethroid. Despite the fact that cypermethrin first made its appearance on the world market in the beginning of the $1970 \mathrm{~s}$, this compound still remains the most utilized insecticide in the world (primarily in the agricultural industry). Cypermethrin as an insecticide / acaricide is manufactured in the form of various commercial products, e.g. "Kinmix". The latter is a racemic mix of cis- and trans- isomers (40:60 proportion) of cypermethrin, predominantly trans-isomers (beta-cypermethrin). Being a broad-spectrum contact-digestive insecticide against larva and grown insects with chewing and piercing-sucking mouthparts (Tsipi et al. 2015) $\beta$ cypermethrin and its isomers (just like other synthetic pyrethroids) bind to the lypophilic cell membranes and act on the voltage-gated sodium channel proteins of the nerve cells. The depolarization of the membrane and slowing of sodium channel opening or closing ensues as the result. The speed of sodium ions in such a pyrethroid-modified channel is changing as well as the strong depolarization flow of sodium ions is emerging (due to the CN-group contained in cypermethrin) causing repeating discharges and giving rise to synaptic disruptions (Vijverberg, van den Bercken 1990).

Cypermethrin being a 3rd degree hazard material for humans according to the official classification (Xuanwei et al. 2016) is characterized by a widespread application. Even though a variety of methods are 
suggested to use for its detection, including gas chromatography (Chen et al. 2014; Joia et al. 1985; Sassine et al. 2004), high performance liquid chromatography (HPLC) with various detectors (Bissacot, Vassilieff 1997; Liu et al. 2012; Radford et al. 2016), as well as using mass spectrometry of low and high definitions, the task of highly sensitive and selective cypermethrin detection in the objects of toxicological control remains relevant. All-in-all, mass spectrometry method of cypermethrin detection in objects of toxicological control combined with simplicity and affordability of tabletop GC-MS instruments (Fitsev et al. 2004; Grimalt, Dehouck 2016; Gurbuz et al. 2014; Watson 1976) equipped with the expert database mass-spectra appears to be the optimal solution for its detection in objects of toxicological control.

The goal of this research is the developing a GC-MS cypermethrin detection protocol in the objects of toxicological control using a SPE during the sample preparation.

\section{MATERIALS AND METHODS}

The following equipment was used: gas chromatograph «Trace 1300» with a mass-spectrometer «DSQ» (Thermo Fisher Scientific, USA), monitoring electronic ionization specters (EI, $70 \mathrm{eV}$ ) in the range $\mathrm{m} / \mathrm{z}=30-550$. Qualitative and quantitative GC-MS analysis was performed on a fused silica column «TraceGold TG-5 MS» $(30 \mathrm{~m} \times 0.25 \mathrm{~mm} \times 0.25 \mu \mathrm{m}$, Thermo Fisher Scientific, USA). Conditions of GC split: injector temperature $-280{ }^{\circ} \mathrm{C}$, interface temperature $-280{ }^{\circ} \mathrm{C}$, initial thermostat temperature $-70{ }^{\circ} \mathrm{C}$, column's rate of temperature elevation $-10^{\circ} \mathrm{C} / \mathrm{min}$, final temperature of column's thermostat $-280{ }^{\circ} \mathrm{C}$, splitless injection, sample size $-1 \mu \mathrm{l}$, volume velocity of gas vehicle $(\mathrm{He}, 99,999 \%)-0,9 \mathrm{ml} / \mathrm{min}-$ constant flow.

Processing of mass-spectral data was done using software tool «Xcalibur» (Thermo Fisher Scientific, USA), electronic mass-spectrum library «NIST’17», «NIST MS Search Program V. 2.3», «NIST MS Interpreter» (NIST, USA).

Regression analysis of calibration characteristics and mathematical forecasting of peak area response was done using software tool «Origin V. 6.1» (OriginLab Corp, USA), and their processing performed according to the requirements specified in the normative documents (ISO/IEC Guide 98-1 2009; Rabinovich 2017).

In the course of GC-MS research, the following reagents were used for obtaining the calibration curve of "analytical signal - analyte content" as well as for validity and convergence checks: analytical standard «Pestanal ${ }^{\circledR}(98 \%$, CAS №52315-07-8, catalogue №36128, Supelco, USA). Analyte solutions $\left(1000 \mu \mathrm{g} \cdot \mathrm{L}^{-1}\right)$, as well as working solutions for setting up calibration dependencies were prepared with the absolute acetone of «for HPLC». The following were used as well: hexane, acetonitrile, methanol «for HPLC». Concentration cartridges of increased capacity and selectivity on the basis of sorbent with chemically bonded octadecyl groups «Diapak C18 Plus» were used for SPE (BioChemMac, Russia).

\section{RESULTS AND DISCUSSION}

GC-MS of analyte standard solution $\left(\mathrm{C}=25 \mu \mathrm{g} \cdot \mathrm{L}^{-1}\right)$ demonstrated the presence of four peaks of total ion current on its chromatogram (Figure 1) which relate accordingly to cis-1 (29.33 min), cis-2 (29.50 min), trans-1 (29.61 min) and trans-2 (29.68 $\mathrm{min}$ ) respectively diastereomers of cypermethrin. A better split of cis- and trans-isomers in the GC conditions is possible with the use of the greater-length column, however it would not lead to significant results, since the full split of cypermethrin geometrical and optical isomers could be achieved only with the use of Reversed Phase (RP) HPLC (Hu et al. 2015; Naobumi et al. 1990), which would also allow assessing the biological effectiveness of substances containing cypermethrin based on the information on the content of most active cis-forms. The data presented in figure 1 shows that relative intensity of analytical signals of sum of 
cis- and sum of trans- isomers of cypermethrin is characterized by the proportion of 40:60, which is comparable to the data presented in (Kutter, Class 1992; Nosikova, Kochetov 2017; Yu 2000). Mass-spectrum of EI cypermethrin and main directions of dissociative ionization of its molecule are presented in Figure. 2.

Export of mass-spectrum EI peaks with the retention levels 29.33, 29.50, 29.61 and 29.68 min (using software «Xcalibur») into the electronic library of mass-spectrums «NIST'17» and its subsequent identification on the characteristic ions using a Relative Match Factor $(R M F)$ generated by software too «NIST MS Search Program» of cypermethrin molecule EI mass-spectrum from the above-mentioned library showed high level of RMF at 930-945 respectively. This circumstance confirms the correct identification of cypermethrin by registering total ion current on its EI mass-spectrum (Figure 2).

The data presented in Figure 2 show that dissociative EI of cypermethrin molecule goes in two competing directions with the forming of ions $\mathrm{m} / \mathrm{z}=208\left(\mathrm{C}_{14} \mathrm{H}_{10} \mathrm{NO}^{+}, 40 \%\right)$ and $\mathrm{m} / \mathrm{z}=207\left(\mathrm{C}_{8} \mathrm{H}_{9} \mathrm{Cl}_{2} \mathrm{O}_{2}{ }^{+}, 39 \%\right)$. In its turn, the separation of $\mathrm{CN}$-group $(\mathrm{m} / \mathrm{z}=26)$ from $\mathrm{C}_{14} \mathrm{H}_{10} \mathrm{NO}^{+}$leads to the formation of ion $\mathrm{m} / \mathrm{z}=181\left(\mathrm{C}_{13} \mathrm{H}_{9} \mathrm{O}^{+}, 89 \%\right)$, and detaching of $\mathrm{CO}_{2}(\mathrm{~m} / \mathrm{z}=44)$ from $\mathrm{C}_{8} \mathrm{H}_{9} \mathrm{Cl}_{2} \mathrm{O}_{2}{ }^{+}$comes with the formation of ion $\mathrm{m} / \mathrm{z}=163\left(\mathrm{C}_{7} \mathrm{H}_{9} \mathrm{Cl}_{2}{ }^{+}, 100 \%\right)$, which has a maximum intensity in the mass-spectrum of EI cypermethrin molecule. Intensive values $\mathrm{m} / \mathrm{z}=127$ (45\%) correspond to formation of ion $\mathrm{C}_{7} \mathrm{H}_{11} \mathrm{O}_{2}{ }^{+}, \mathrm{m} / \mathrm{z}=91$ (41 \%)l-formation of ion $\mathrm{C}_{7} \mathrm{H}_{7}{ }^{+}$, and $\mathrm{m} / \mathrm{z}=77$ (33\%) - formation of ion $\mathrm{C}_{6} \mathrm{H}_{5}{ }^{+}$. Therefore, the ions with $\mathrm{m} / \mathrm{z}=163,181,127$ have the greatest intensity in cypermethrin mass-spectrum.

We subsequently applied the strategy of identifying cypermethrin by its most characteristical and intensive ions of mass-spectrum EI m / z=163 (principal ion), $\mathrm{m} / \mathrm{z}=181$ and m / z=127 (confirmation ions) to build the calibration curve «analyte sygnal - analyte content» for cis-1, cis-2 and trans-1, trans-2 isomers of cypermethrin in order to utilize it for the their detection in the objects of toxicological control.

Experimental equations for calibration curves for the sum of cypermethrin cis-1, cis-2 and trans-1, trans-2 isomers, received during calibration of MS-detector $" D S Q$ » using analytical standard "Pestanal ${ }^{\circledR}$ » in selective ion monitoring mode $(\mathrm{m} / \mathrm{z}: 163,181,127)$ as well as their metrological characteristics are presented in Table 1.

The data provided in Table 1 show that the LOD of all forms of cypermethrin for GC-MS and calculation with $3 \cdot S$-criterium was $3 \mu \mathrm{g} \cdot \mathrm{kg}^{-1}$.

The check of the extraction, accuracy, convergence and results' reproducibility for the determination of cypermethrin cis- and trans- isomers was done using an «Injected - Detected» method (see Table 2) after the SPE stage according to current approach in analytical chemistry (Goncalves, Alpendurada 2004; Mogadati et al. 1999; Redondo et al. 1996).

SPE using «Diapak C18» cartridges included a standard flushing procedure by $10 \mathrm{ml}$ of acetonitrile, then with an acetonitrile-water mix (1:1) and subsequent elution with 4 portions of $5 \mathrm{ml}$ of the acetonitrile-water mix (4:1) through the cartridge of cypermethrin's acetonitrile-water solution. The fractions collected in the glass receiver were evaporated dry via a rotary evaporator under the temperature of $30^{\circ} \mathrm{C}$, and subsequently dissolved into $1 \mathrm{ml}$ of acetone and analyzed under GC-MS protocol with the registration of selective ions. After receiving the GC-MS analysis results, the analyte content in the sample was calculated as well as the completeness of its extraction from cartridge and the necessary volume of eluent which amounted to $15 \mathrm{ml}$. The results provided in Table 2 show that completeness of cypermethrin cis- and trans- isomers' extraction amounts to $94.3 \pm 6.1 \%$.

The developed method of GC-MS cypermethrin detection with SPE sample preparation was applied to analyze the 
sample of raw food materials and food products, as well as to the tissues of animal and insects. Determination results are provided in Table 3.

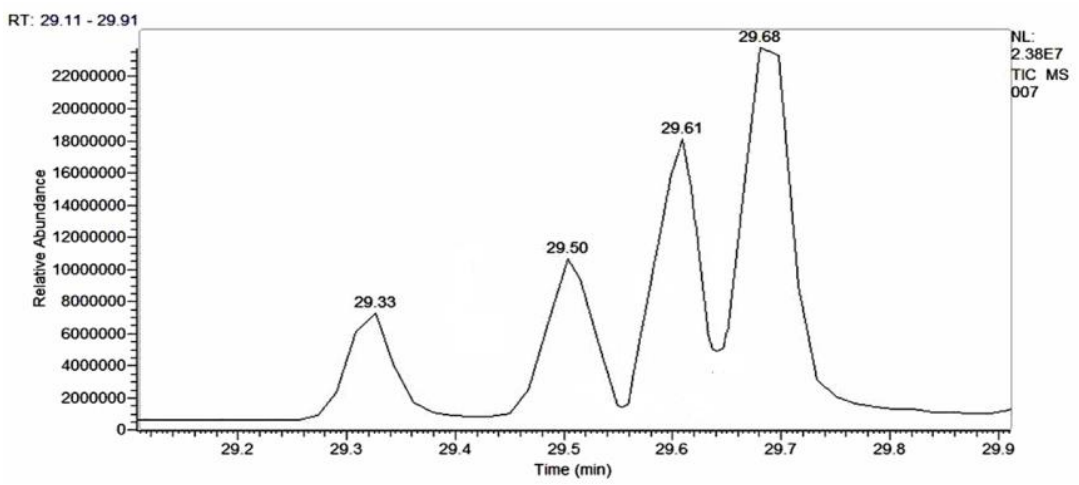

Figure 1: Total Ion Chromatogram (TIC MS) of Analytical Standard Cypermethrin Solution (C=25 Mg.L-1) Cis-1 (29.33 Min), Cis-2 (29.50 Min), Trans-1 (29.61 Min) and Trans-2 (29.68 Min) Respectively Diastereomers of Cypermethrin.

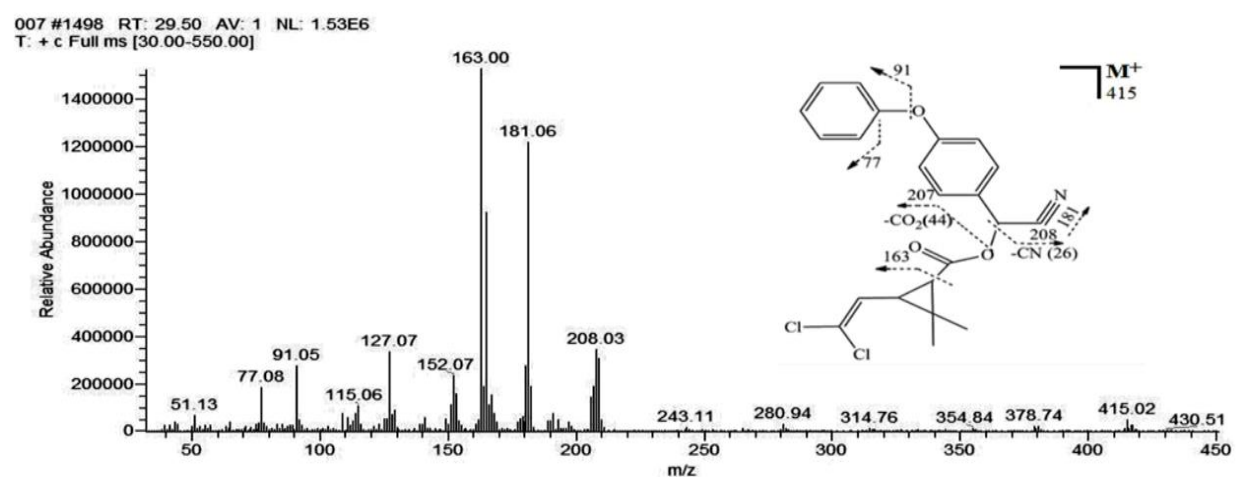

Figure 2: Graphical Representation of EI Mass-Spectrum (70 Ev) and Main Directions of Cypermethrin Molecule's Dissociative Ionization.

Table 1: Characteristics of Calibration Curves for the Cypermethrin Cis-1, Cis-2 and Trans-1, Trans-2 Isomers Received Using Analyte Standard Solutions for MS-Detector «DSQ II»

\begin{tabular}{|c|c|c|c|c|}
\hline $\begin{array}{l}\text { Determined } \\
\text { Compound Form }\end{array}$ & $\begin{array}{c}\text { Ordinary Least Squares } \\
\text { Estimation Equation } \\
Y=\left(A \pm S_{a}\right)+\left(B \pm S_{b}\right) \cdot X \\
\text { Where } Y \text { Is The Relative } \\
\text { Ionic Current And } X \text { Is The } \\
\text { Cypermethrin } \\
\text { Concentration, } \mathrm{Mg} / \mathrm{Kg}\end{array}$ & $\begin{array}{c}\text { Correlation } \\
\text { Coefficient }\left(\boldsymbol{R}^{2}\right)\end{array}$ & LOD $\left(\mathbf{M g} \cdot \mathbf{K g}^{-1}\right)$ & $\begin{array}{c}\mathrm{LOQ}^{*} \\
\left(\mathbf{M g} \cdot \mathbf{K g}^{-1}\right)\end{array}$ \\
\hline cis-1 isomer & $\begin{array}{c}\mathrm{y}=(424.3 \pm 62.3)+(62439,4 \\
\pm 113.2) \cdot x\end{array}$ & $0.998(n=10)$ & 3.0 & 8.0 \\
\hline cis-2 isomer & $\begin{array}{c}\mathrm{y}=(494.0 \pm 52.4)+(51465,2 \\
\pm 125.1) \cdot x\end{array}$ & $0.999(n=10)$ & 3.0 & 8.0 \\
\hline trans- 1 isomer & $\begin{array}{c}\mathrm{y}=(489.2 \pm 71.2)+(75116.3 \\
\pm 120.1) \cdot x\end{array}$ & $0.997(n=10)$ & 3.0 & 8.0 \\
\hline trans-2 isomer & $\begin{array}{c}y=(411.4 \pm 44.2)+(45465.3 \\
\pm 105.1) \cdot x\end{array}$ & $0.999(n=10)$ & 3.0 & 8.0 \\
\hline
\end{tabular}

Limit of Quantitification 
Gas Chromatography-Mass Spectrometry with Solid-Phase Extraction

Table 2 Results of Cypermethrin Detection Recovery Rate After Applying SPE «Injected - Detected» Method, Confidence Interval for the Average and Its Standard Deviation Under GC-MS Conditions (by the Sum of Cis- and Trans- Isomers $)(\mathrm{N}=10, \mathrm{P}=\mathbf{0 , 9 5})$

\begin{tabular}{|c|c|c|c|c|}
\hline $\begin{array}{l}\text { Injected, } \\
\mathbf{M g} \cdot \mathbf{L}^{-1}\end{array}$ & $\begin{array}{c}\text { Detected, }\left({ }_{x}^{-} \pm\right. \\
\left.\Delta_{x}^{-}\right), \mathbf{M g} \cdot \mathbf{L}^{-1}\end{array}$ & $\begin{array}{c}\text { Average Detection } \\
\text { Rate, }{ }_{x}^{-}, \%\end{array}$ & $\begin{array}{c}\text { Average Detection Rate } \\
\text { Confidence Interval, } \pm \Delta_{x}^{-}, \%\end{array}$ & $\begin{array}{c}\text { Standard } \\
\text { Deviation, } S, \%\end{array}$ \\
\hline $3.00 \cdot 10^{-2}$ & $(2.80 \pm 0.19) \cdot 10^{-2}$ & 94.3 & \pm 6.2 & 4.2 \\
\hline $5.00 \cdot 10^{-2}$ & $(4.72 \pm 0.30)^{\cdot} 10^{-2}$ & 94.4 & \pm 5.9 & 4.1 \\
\hline $6.00 \cdot 10^{-2}$ & $(5.70 \pm 0.40) \cdot 10^{-2}$ & 94.2 & \pm 6.1 & 4.0 \\
\hline $1.00 \cdot 10^{-1}$ & $(9.43 \pm 0.62) \cdot 10^{-2}$ & 94.3 & \pm 6.2 & 4.0 \\
\hline $1.20 \cdot 10^{-1}$ & $(1.13 \pm 0.08) \cdot 10^{-1}$ & 94.4 & \pm 6.3 & 4.0 \\
\hline
\end{tabular}

Table 3 Results of Cypermethrin Content Determination (By the Sum of Cis- and Trans-Isomers) in Objects of Toxicological Control (Raw Food Material, Food Products, Animal and Insect Tissues). (N=6, P=0, 95)

\begin{tabular}{|c|c|c|c|}
\hline Research Object & $\begin{array}{c}\text { Found, }\left(\begin{array}{c}x \pm \Delta_{x} \\
\mathbf{M g} \cdot \mathbf{K g}^{-1}\end{array}\right.\end{array}$ & $\begin{array}{c}\text { Standard } \\
\text { Deviation, } S, \%\end{array}$ & $\begin{array}{l}\text { Toxicological Data - Maximum Admissible } \\
\text { Concentration, } \mathrm{Mg} \cdot \mathrm{Kg}^{-1} \text { According To } \\
\text { Criteria82 Cypermethrin (Albert } \mathrm{Et} \text { Al. 1989) }\end{array}$ \\
\hline $\begin{array}{l}\text { All parts (except for the root } \\
\text { system) of the plant } \\
\text { Hordeum (barley) } \\
\text { vegetation / seed formation } \\
\text { period }\end{array}$ & $(9.20 \pm 0.60) \cdot 10^{-1}$ & 4.0 & ( \\
\hline $\begin{array}{l}\text { All parts (except for the root } \\
\text { system) of the plant } \\
\text { Brassica napus (Colza) } \\
\text { vegetation / blossoming } \\
\text { period }\end{array}$ & $(0.90 \pm 0.05)^{\cdot} 10^{-1}$ & 4.1 & 0.1 \\
\hline $\begin{array}{l}\text { Aboveground portion of } \\
\text { Solánum tuberósum } \\
\text { (Potato) vegetation / } \\
\text { tuberization period }\end{array}$ & $(1.00 \pm 0.05)^{\cdot} 10^{-1}$ & 4.0 & - \\
\hline $\begin{array}{l}\text { Plant tuber Solánum } \\
\text { tuberósum (Potato) } \\
\text { egetation / tuberization } \\
\text { period }\end{array}$ & $(0.22 \pm 0.02) \cdot 10^{-1}$ & 4.0 & 0.05 \\
\hline Chicken egg & $(0.51 \pm 0.03)^{\cdot} 10^{-1}$ & 4.0 & 0.10 \\
\hline $\begin{array}{l}\text { Domestic fowl tissue Gallus } \\
\text { domesticus (Chicken) }\end{array}$ & $(0.92 \pm 0.06)^{\cdot} 10^{-1}$ & 4.0 & 0.05 \\
\hline $\begin{array}{l}\text { Insect tissue Apis mellifera } \\
\text { (honey bee) }\end{array}$ & $(0.23 \pm 0.05)^{\cdot} \cdot 10^{-1}$ & 4.0 & $\mathrm{LD}_{50} 3.3 \cdot 10^{-5} \mathrm{mg} \square /$ individual \\
\hline $\begin{array}{c}\text { Laboratory animal tissue } \\
\text { Ratus (rat) }\end{array}$ & $(2.53 \pm 0.03) \cdot 10^{-1}$ & 4.0 & $\mathrm{LD}_{50}$ for rats $250-300 \mathrm{mg}$ \\
\hline
\end{tabular}

\section{CONCLUSIONS}

Method for GC-MS quantitative determination of cypermethrin in objects of toxicological control (raw food material, food products, animal and insect tissues) with SPE stage for sample preparation on the basis of sorbent with chemically bonded octadecyl groups in cartridges of «Diapak C18 Plus» was developed. For quantitative determination of cypermethrin by GC-MS (EI, $70 \mathrm{eV}$ ) monitoring of selective ions was used with parameters of $\mathrm{m} / \mathrm{z}=163$ (principal ion), and $\mathrm{m} / \mathrm{z}=181,127$, (confirmation ions), which allowed achieving the cypermethrin LOQ of $8 \mu \mathrm{g} \cdot \mathrm{kg}^{-1}$. 


\section{ACKNOWLEDGMENTS}

The team of authors expresses appreciation for the analytical equipment used in the present work of the Test Center of the Federal Center for Toxicological, Radiation and Biological Safety (Kazan).

Conflict of Interest: I.M. Fitsev declares that he has no conflict of interest. O.V. Shlyamina declares that she has no conflict of interest. A.R. Makaeva declares that she has no conflict of interest. G.R. Nasybullina declares that he has no conflict of interest. A.M. Saifutdinov declares that he has no conflict of interest

Ethical Approval: This article does not contain any studies with human participants or animals performed by any of the authors.

Informed Consent: Informed consent was obtained from all individual participants included in the study.

\section{REFERENCES}

1. Bissacot, D. Z.; Vassilieff, I. (1997) HPLC determination of flumethrin, deltamethrin, cypermethrin, and cyhalothrin residues in the milk and blood of lactating dairy cows. J Anal Toxicol 21, 397-402.

2. Chen, H. P.; Yin, P.; Wang, Q. H.; Jiang, Y.; Liu, X. (2014) A modified QuEChERS sample preparation method for the analysis of 70 pesticide residues in teausing gas chromatography-tandem mass spectrometry. Food Anal Methods 7, 15771587.

3. Fitsev, I. M,; Blokhin, V. K.; Budnikov, G. K. (2004) Chromatographic techniques in forensic chemical examinations. J of Anal Chem 59, 1171-1180.

4. Goncalves, C.; Alpendurada, M. F. (2004) Solid-phase micro-extraction-gas chromatography-(tandem) mass-spectrometry as a tool for pesticide residue analysis in water samples at high sensitivity and selectivity with confirmation capabilities. J. Chromatogr. A. 1026, 239-250.

5. Gurbuz, N.; Arik, O.; Baykal, A. (2014) Screening of pesticide residues in fresh vegetables and fruits by LC-MS/MS and GCMS/MS. Asian Journal of Chemistry, 26, 6975-6981.

6. Grimalt, S.; Dehouck, P. (2016) Review of analytical methods for the determination of pesticide residues in grapes. J Chromatogr A 1433, 1-23.

7. Hu, W.; Xie, W.; Chen, S.; Zhang, N.; Zou, Y.; Dong, X.; Rashid, M.; Hu, Y.; Xia, M.; Zhong, G. (2015) Separation of cis-and trans-cypermethrin by reversedphase high-performance liquid chromatography. J. Chromatogr. Sci., 53, 612618.

8. Albert, L., Budd, E., Bwititi, T.P., Deema, S., Desi, I., El Sebae, A.K.H., Goulding, R., Jeyaratnam, J., Osman, Y., Takanaka, A., Punja, N., Shaw, J. (1989) IPCS. Environmental Health Criteria 82. Cypermethrin. World Health Organization, Geneva.

9. (2009) ISO/IEC Guide 98-1 Uncertainty of measurement-Part 1: introduction to the expression of uncertainty in measurement. International Organization for Standardization (ISO). Geneva.

10. Joia, B. S.; Sarna, L. P; Webster, G. R. B. (1985) Gas chromatographic determination of cypermethrin and fenvalerate residues in wheat and milled fractions. Intern J Environ Anal Chem 21, 179-184.

11. Kutter, J. P.; Class, T. J. (1992) Diastereoselective and enantioselective chromatography of the pyrethroid insecticides allethrin and cypermethrin. Chromatographia., 33, 103112.

12. Liu, S.; Yao, K.; Jia, D.; Zhao, N.; Lai, W.; Yuan, H. (2012) Pretreatment method for HPLC analysis of cypermethrin in microbial degradation. J. Chromatogr. Sci., 50, 469476. 
13. Mogadati, P.; Louis, J. B.; Rosen, J. D. (1999) Multiresidue determination of pesticides in high-organic-content soils by solidphase extraction and gas chromatography/mass spectrometry. Journal of AOAC International, 82, 705715.

14. Naobumi, O.; Hajimu, K.; Reiko, K. (1990) Enantiomer separation of pyrethroid insecticides by high performance liquid chromatography with chiral stationary phase. J Chromatogr A., 515, 441450.

15. Nosikova, L. A, Kochetov A. N. (2017) Establishment of isomeric composition of insecticidal cypermethrin substance by RPHPLC. Fine Chemical Technologies, 12, 7682.

16. Rabinovich, S.G. (2017) Evaluating measurement accuracy. A practical approach. New York: Springer.

17. Radford, S. A.; Panuwet, P.; Hunter, R. E.; Barr, D. B.; Ryan, P. B. (2016) Production of insecticide degradates in juices: implications for risk assessment. J. Agr. Food. Chem., 64, 4633-4638.

18. Redondo, M. J.; Ruiz, M. J.; Boluda, R.; Font, G. (1996) Optimization of a solid-phase extraction technique for the extraction of pesticides from soil samples. J. Chromatogr. A., 719, 6976.

19. Sassine, A.; Moura, S.; Leo, V. M.; Bustillos, O. V. (2004) Cypermethrin residues determination in the milk of a lactating dairy cow by gas chromatography-ion trap mass spectrometry J. Anal. Toxicol. 28, 238-241.

20. Tsipi, D.; Botitsi, H.; Economou, A. (2015) Mass spectrometry for the analysis of pesticide residues and their metabolites. New York: J. Wiley \& Sons Inc.

21. Vijverberg, H. P.; van den Bercken, J. (1990) Neurotoxicological effects and the mode of action of pyrethroid insecticides. Crit Rev Toxicol 21, 105-126.

22. Watson, J.T. (1976) Introduction to mass spectrometry: biomedical, environmental, and forensic user Applications, New York: Raven Press.

23. Xuanwei, X.; Shuang, L; Yueru, LI.; Zhongbin, LU. (2016) Pesticide residue rapid extraction from ginseng tea using a modified Luke method for GC-MS. Food Anal Methods 9, 2231-2240.

24. Yu, Y. (2000) Separating and determining cypermethrin optical isomer with GC/MS. J. Chin. Mass Spectrom, Soc., 21, 2324. 

